\title{
KARAKTERISASI KONDUKTIVITAS TERMAL DAN KEKERASAN KOMPOSIT ALUMINIUM MATRIK PENGUAT HIBRID SiCw/AL $\mathrm{L}_{2} \mathrm{O}_{3}$
}

\author{
Ketut Suarsana $^{1)}$, I Made Astika ${ }^{2)}$, Lega Suprapto ${ }^{3)}$ \\ ${ }^{1}$ Jurusan Teknik Mesin, Universitas Udayana Denpasar Bali \\ Email: ktsuarsana@yahoo.com \\ 2 Jurusan Teknik Mesin, Universitas Udayana Denpasar Bali \\ Email: imdastika@yahoo.com \\ ${ }^{3}$ Jurusan Teknik Mesin, Program Magister, Universitas Udayana Denpasar Bali \\ Email: legasuprapto71@gmail.com
}

\begin{abstract}
ABSTRAK
Sifat komponen mesin kuat, ringan dan murah merupakan persyaratan utama dalam dunia industri mesin. Persyaratan ini memunculkan inovasi dalam pembuatan komposit menggunakan matrik berbasis Aluminium diperkuat Silicon Carbon wisker dan alumina partikel $\left(\mathrm{Al}_{2} \mathrm{O}_{3} p\right)$. Karakteristik komposit dipengaruhi oleh komposisi bahan matrik dengan penguatnya, serta pengaruh temperatur dan perlakuan sintering. Tujuan dari penelitian ini adalah untuk mendapatkan karakteristik komposit baru aluminium matrik composite (AMC) dari bahan Al fine powder sebagai matrik diperkuat dengan gabungan hibrid silicon carbon whiskers (SiCw) dan alumina partikel $\left(\mathrm{Al}_{2} \mathrm{O}_{3} \mathrm{p}\right)$, melalui metode powder metalurgi pada perlakuan setelah sintering. Metode pembuatan komposit dengan cara metalurgi serbuk (powder metallurgy) yaitu ketiga variasi bahan dimasukan dalam cetakan kemudian diberi gaya tekan 2,5 ton dengan waktu penahanan 15 menit. Variasi komposisi bahan adalah $\mathrm{Al}$ : ( $\left.\mathrm{SiCw}_{\mathrm{C}} \mathrm{Al}_{2} \mathrm{O}_{3}\right)$ pada komposisi I, komposisi II dan komposisi III. Setelah terbentuk spesimen material komposit dikenakan perlakuan sintering dengan variasi suhu adalah: $500^{\circ} \mathrm{C}, 550^{\circ} \mathrm{C}$ dan $600^{\circ} \mathrm{C}$ dan holding time : 1 jam, 3 jam dan 6 jam. Specimen uji dibuat sebanyak 81 buah dengan masing-masing 3 buah spesimen untuk setiap kombinasi perlakuan temperatur dan holding time. Dari penelitian koduktivitas termal yang dilakukan didapat hasil tertinggi adalah $455.111 \mathrm{k}\left(\mathrm{W} / \mathrm{m} .{ }^{\circ} \mathrm{C}\right)$ pada temperatur $600^{\circ} \mathrm{C}$ dengan waktu 6 jam dan terendah didapat $34.874 \mathrm{k}\left(\mathrm{W} / \mathrm{m} .{ }^{\circ} \mathrm{C}\right) \mathrm{pada}$ perlakuan sintering $500^{\circ} \mathrm{C}$ dengan holding time 1 jam. Begitu juga kekerasan tertinggi terjadi pada $141.046 \mathrm{VHN}$ dan yang terendah dari penelitian didapat 128.750 VHN, jadi komposisi mempengaruhi konduktivitas termal dan kekerasan komposit.
\end{abstract}

Kata kunci : Karakteristik termal, kekerasan, hibrid $\mathrm{SiCw}$ dan $\mathrm{Al}_{2} \mathrm{O}_{3}$.

\section{PENDAHULUAN}

Perkembangan teknologi yang begitu pesat memerlukan material teknik dan cara produksi yang tepat untuk mewujudkan sebuah produk berkualitas, harga relatif murah. Material teknik yang memiliki sifat-sifat seperti ringan, tahan aus, kuat, keras, murah dan mudah diproduksi, sangat memungkinkan sebagai material alternatif untuk menggantikan fungsi material logam berat seperti besi atau baja. Salah satu bahan yang memenuhi sebagian sifat-sifat tersebut adalah material berbahan matrik aluminium, karena aluminium merupakan logam yang ringan, murah dan mudah diproduksi. Untuk mendapatkan material yang kuat, sifat keras, densitas rendah, ketahanan abrasi, ketahanan aus, tahan korosi dan penghantar panas yang baik, bisa didapat dengan mengkombinasikan beberapa jenis material konversional dengan logam untuk dikembangkan menjadi material komposit. Material komposit dikembangkan untuk meningkatkan kualitas sifat mekanik, fisik, maupun ketahanan aus serta muai termal yang baik. Silicon carbide $(\mathrm{SiC})$ memiliki sifat-sifat seperti kekerasan tinggi dan tahan terhadap temperatur tinggi serta mampu dibasahi cukup baik oleh Al sehingga memungkinkan untuk dipadukan. Persentase berat $\mathrm{Al}-\mathrm{SiC}$ yang diperkuat $20 \%$ partikel $\mathrm{SiC}$ lebih ringan $57 \%$ dibanding berat baja, serta ketahanan aus dan konduktivitas termalnya tinggi (Zainuri, at,.al 2009). Kompaktibilitas komposit Isotropik $\mathrm{Al} / \mathrm{Al}_{2} \mathrm{O}_{3}$ yang dibuat dari aluminium sebagai matrik dan $\mathrm{Al} / \mathrm{Al}_{2} \mathrm{O}_{3}$ sebagai penguat dengan variabel fraksi volume penguat yang digunakan adalah 10\%, 20\%, 30\% dan $40 \%$. Temperatur sintering $600^{\circ} \mathrm{C}$ dan gaya tekan kompaksi $15 \mathrm{kN}$. Hasil yang diperoleh adalah kompaktibilitas komposit $\mathrm{Al} / \mathrm{Al}_{2} \mathrm{O}_{3}$ mencapai nilai optimun saat waktu tahan sintering 2 jam. Sepanjang proses sintering, fasa baru yang terbentuk adalah alumina tidak stabil. Fraksi volum penguat terbaik adalah $40 \%$ dan waktu tahan sintering optimum adalah 2 jam (Widyastuti, et al. 
2008). Mengacu dari hasil-hasil penelitian sebelumnya, terlihat disini belum ada yang meneliti karakteristik konduktivitas termal pada material komposit $\mathrm{Al} /\left(\mathrm{SiCw}+\mathrm{Al}_{2} \mathrm{O}_{3}\right)$, hal ini perlu selain material kuat juga bagaimana kemampuan sifat penghantar panas.

\section{METODE PENELITIAN}

\section{Bahan Penelitian}

Aluminium fine powder dipilih sebagai bahan matriks dengan kemurnian di atas $90 \% \quad(\geq 90 \%$ p.a Merck), densitas $(\rho)=2,7 \mathrm{gr} / \mathrm{cm}^{3}$ dan kekerasan 75-95 Hv, dengan ukuran butir 32 sampai 45 $\mu \mathrm{m}$. Serat $\mathrm{SiCw}$ komersial dengan diameter $(\mathrm{d})=0,45-0,65 \mu \mathrm{m}$, panjang $(\mathrm{l})=5-80 \mu \mathrm{m}$, kerapatan $(\rho)=3,2 \mathrm{gr} / \mathrm{cm}^{3}$, kekerasan $=2400 \mathrm{Hv}$. Bahan serbuk $\mathrm{Al}_{2} \mathrm{O}_{3}$ p dengan densitas $(\rho)=$ $3,8 \mathrm{gr} / \mathrm{cm}^{3}$, ukuran butir 1 sampai $5 \mu \mathrm{m}$, kekerasan $=1800 \mathrm{Hv}$ digunakan sebagai penguat. Selain itu larutan $96 \%$ Ethanol $\left(\mathrm{CH}_{3} \mathrm{COOH}\right)$ digunakan sebagai media pencampur serta Vaseline sebagai pelumas pada dinding cetak tekan. Material komposit dari aluminium matrik komposit dibuat dengan teknik metalurgi serbuk menggunakan bahan baku serbuk yaitu Al fine powder, serat $\mathrm{SiC}$ whisker komersial dan alumina partikel $\left(\mathrm{Al}_{2} \mathrm{O}_{3}\right)$. Proses pencampuran aluminium matrik dengan penguat $\mathrm{SiCw}$ dan $\mathrm{Al}_{2} \mathrm{O}_{3}$ dilakukan pencampuran basah (wet mixing). Bahan aluminium serbuk halus dengan penguat $\left(\mathrm{SiC}+\mathrm{Al}_{2} \mathrm{O}_{3}\right)$ dimasukkan ke dalam gelas beaker dengan menambahkan pelarut polar berupa ethanol. Perbandingan volume antara serbuk $\mathrm{Al}-\mathrm{SiC}_{\mathrm{Al}} \mathrm{Al}_{3}$ terhadap larutan ethanol adalah $1: 2$. Kemudian pengadukan dilakukan dengan alat magnetic stirrer dilengkapi dengan hot plate pada suhu $50^{\circ} \mathrm{C}$, selama 30 menit sampai tercampur merata. Selanjutnya campuran serbuk ini dikeringkan dalam furnace pada suhu $100^{\circ} \mathrm{C}$ selama 60 menit guna menguapkan sisa larutan ethanol sampai kering sempurna (Ryuichiro, 2013). Kemudian campuran tersebut dimasukkan kedalam cetakan bentuk silinder yang sebelumnya dinding cetakan telah diolesi vaselin sebagai pelumas. Proses penekanan dilakukan dengan alat hydraulic press "Carver" pada temperatur kamar yaitu cold compactions. Tekanan yang digunakan sebesar $25 \mathrm{~N}$ dan ditahan selama 5 menit agar distribusi tegangan merata dan menghindari terbentuknya oksidasi pada komposit matrik aluminium. Cetakan berbentuk silendris, sehingga spesimen didapat berbentuk silinder dengan dimensi : tinggi $1 \mathrm{~cm}$, diameter $0,8 \mathrm{~cm}$, volume total komposit $\pm 0,5 \mathrm{~cm}^{3}$.
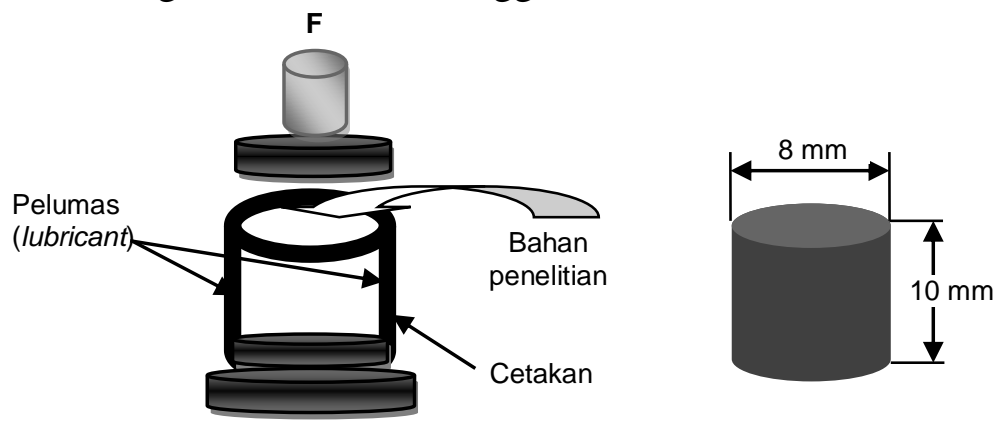

Gambar 1 Spesimen Uji

\section{Penentuan Porositas.}

Pengukuran porositas material komposit $\mathrm{Al} /\left(\mathrm{SiC} w+\mathrm{Al}_{2} \mathrm{O}_{3}\right)$ mengacu pada ASTM C. 373-88. Prosedur pengukuran porositas dari material komposit $\mathrm{Al}+\left(\mathrm{SiC}_{\mathrm{w}}+\mathrm{Al}_{2} \mathrm{O}_{3}\right)$ dilakukan dengan tahapan sebagai berikut (Ahmad, K. R, 2005) :

1. Sampel dikeringkan di dalam dapur pemanas dengan suhu $100^{\circ} \mathrm{C}$ dengan waktu pengeringan selama 2 jam, kemudian timbang massanya dengan neraca digital, disebut massa kering $\left(\boldsymbol{m}_{\boldsymbol{s}}\right)$.

2. Timbang massa kawat penggantung menggunakan neraca digital $\left(\boldsymbol{m}_{\boldsymbol{k}}\right)$.

3. Timbang massa sampel dan penggantungnya (menggunakan kawat) didalam air dengan 
menggunakan neraca digital $\left(\boldsymbol{m}_{\boldsymbol{g}}\right)$.

4. Sampel dicelupkan dalam air hingga massa benda dalam keadaan jenuh, kemudian lap permukaannya dengan kain, dan timbang massanya dengan menggunakan neraca digital $\left(\boldsymbol{m}_{b}\right)$.

Data porositas material komposit $\mathrm{Al} /\left(\mathrm{SiC} w+\mathrm{Al}_{2} \mathrm{O}_{3}\right.$ dinyatakan sebagai porositas terbuka atau apparent porosity, dan dapat d dengan persamaan (Birkeland, 1984).

$$
\mathrm{p}=\frac{m_{b}-m_{s}}{m_{b}-\left(m_{g}-m_{k}\right)} \times 100 \%
$$

dengan : $\mathrm{p}=$ porositas bahan $(\%), \mathrm{m}_{\mathrm{s}}=$ massa sampel setelah dikeringkan di dalam oven, $\mathrm{m}_{\mathrm{b}}=$ massa sampel setelah direndam didalam air sampai jenuh, $\mathrm{m}_{\mathrm{g}}=$ massa sampel yang digantung di dalam air $\mathrm{m}_{\mathrm{k}}=$ massa kawat penggantung sampel.

\section{Konduktivitas Termal}

Nilai kondukitivitas termal suatu bahan menunjukkan laju perpindahan panas yang mengalir dalam suatu bahan. Konduktivitas thermal kebanyakan bahan merupakan fungsi suhu, dan bertambah sedikit kalau suhu naik, akan tetapi variasinya kecil dan sering kali diabaikan. Jika nilai konduktivitas termal suatu bahan makin besar, maka makin besar juga panas yang mengalir melalui benda tersebut. Karena itu, bahan yang harga $k$-nya besar adalah penghantar panas yang baik, sedangkan bila $k$-nya kecil bahan itu kurang menghantar atau merupakan isolator (Garnier, at, al. 2005).

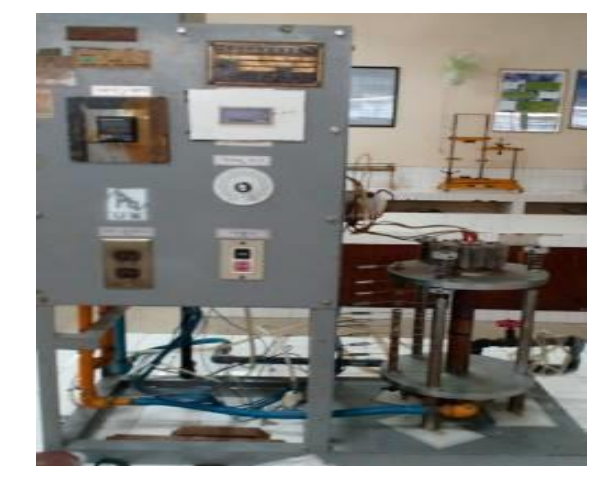

Gambar 2. Alat uji konduktivitas termal Sumber : lab. Universitas brawijaya malang

Untuk menentukan konduktivitas termal melalui rumus :

$\lambda=\frac{\mathrm{Lb} L \mathrm{La}}{\frac{L b}{\lambda b} \cdot \frac{\mathrm{La}}{\lambda a}} \quad \lambda \mathrm{a}=\frac{\Delta t R}{\Delta t a} \cdot \frac{L a}{L R} \cdot \lambda R \quad \lambda \mathrm{b}=\frac{\Delta t R}{\Delta t b} \cdot \frac{L b}{L R} \cdot \lambda R$.

dimana $\mathrm{La}=$ tebal sampel/spesimen yang diuji, dan $\mathrm{Lb}=$ tebal tembaga uji

\section{Penentuan Kekerasan (Vickers Hardness Test)}

Kekerasan material komposit $\mathrm{Al} /\left(\mathrm{SiC}+\mathrm{Al}_{2} \mathrm{O}_{3} \mathrm{p}\right)$ diuji dengan menggunakan Microhardness Tester (Matsuzawa, tipe MXT-50), dan pengujiannya mengacu pada standar ASTM E 18-02 (Dowling,E.N.,1999).

Prosedur uji kekerasan adalah sebagai berikut:

1. Permukaan benda uji terlebih dahulu dipoles hingga rata dan halus dengan menggunakan alat poles.

2. Amplas yang digunakan mulai dari ukuran kasar sampai yang paling halus. Permukaan yang 
baik dan halus akan memantulkan cahaya seperti cermin, karena prinsip pengamatannya berdasarkan pemantulan cahaya.

3. Tempatkan sampel pada holdernya, atur beban dan seting waktu indentasinya 20 detik. Pada pengujian beban yang diberikan sebesar $5 \mathrm{~kg}$.

4. Setelah penekanan, amati indentasi yang dihasilkan, seperti diamond dengan mengatur fokusnya hingga bentuk yang diamati cukup jelas.

5. Ukur panjang masing-masing diagonal dari hasil penekanan tersebut, yang dapat langsung dibaca pada monitor microhardness tester, lakukan minimal 3 kali pengulangan untuk setiap sampel yang diuji.

Kekerasan didefenisikan sebagai ketahanan bahan terhadap penetrasi atau terhadap deformasi dari pemukaan bahan. Ada tiga tipe pengujian terhadap ketahanan, yaitu: cara identasi, pantulan, dan goresan (scratch). Untuk pengujian bahan dengan cara identasi biasanya menggunakan Brinell, Rockwell dan Vickers. Pengujian kekerasan dengan menggunakan Vickers hardness, Umumnya menggunakan alat micro hardness tester yang terbuat dari intan (diamond) dan berbentuk pyramid. Sudut antara permukaan pyramid adalah $\alpha=136^{\circ}$ :

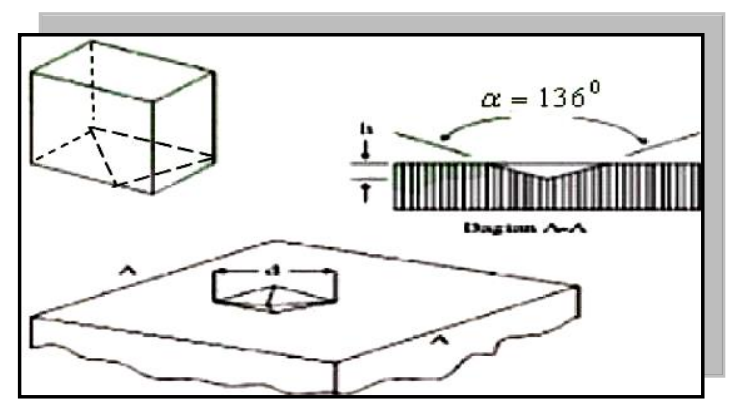

Gambar 3 Skematik Pengujian Kekerasan

Metode pengukuran kekerasan dilakukan dengan uji Vickers, dengan mengacu pada standar ASTM (E 92-82, 2003), angka kekerasan Vickers dengan persamaan :

$$
H V=1,8544 \frac{P}{d^{2}}
$$

Dengan $\mathrm{HV}=$ Kekerasan, $\mathrm{P}=$ Beban, $\mathrm{d}=$ diagonal .

\section{HASIL DAN PEMBAHASAN}

\section{Pengaruh Penguat $\left(\mathrm{SiCw}+\mathrm{Al}_{2} \mathrm{O}_{3}\right.$ p) pada Aluminium terhadap Porositas}

Porositas dapat terjadi akibat terjebaknya lubrikan, gas dan terjadinnya proses perlakuan partikel yang tidak terjadi secara sempurna. Prediksi secara tepat kekuatan mekanik material porus dapat dilakukan dengan mempertimbangkan bentuk, orientasi dan volume porositas. Analisa porositas pada umumnya hanya mempertimbangkan efek fraksi volume porositas dalam kaitannya dengan kekuatan komposit porus (Gibson, 1994). Persyaratan dasar kekuatan komposit terletak pada kualitas kekuatan antarmuka matrik dan penguat. Ikatan antarmuka inilah yang menjadi jembatan transmisi tegangan luar yang diberikan dari matrik menuju partikel penguat. Jika ikatan yang terjadi antara matrik dengan penguat dengan baik maka transmisi tegangan ini dapat berlangsung dengan baik dan kuat. Keberadaan porus yang terletak pada daerah antarmuka antar serbuk matrik dan penguat menyebabkan terhalangnya pembentukan ikatan antar partikel penguat sepanjang proses kompaksi maupun pembentukan sepanjang proses sintering. Porositas 
juga merupakan pusat konsentrasi tegangan eksternal yang dapat menurunkan kemampuan material dalam menahan beban eksternal.

Pada komposit $\mathrm{Al} /\left(\mathrm{SiC}+\mathrm{Al}_{2} \mathrm{O}_{3} \mathrm{p}\right)$ porositas terjadi pada daerah antar muka matrik dan penguat. Keberadaan porositas menyebabkan penurunan sifat mekanik komposit. Pada umumnya total porositas banyak dipengaruhi oleh serat $\mathrm{SiCw}$ yang orientasinya secara acak atau random pada komposit. Hal ini berakibat ikatan antarmuka serbuk aluminium dengan serat $\mathrm{SiCw}$ menimbulkan pori lebih banyak dibandingkan dengan serbuk Al dipadukan dengan alumina partikel. Selain itu porositas sangat berhubungan erat dengan kompaktibilitas, semakin kecil ukuran serbuk maka luas kontak permukaan antar butir semakin luas (Suarsana \& Sunu, 2015). Bila porositas semakin kecil maka sifat kompaktibilitas bahan semakin tinggi. Porositas bahan dapat ditentukan dengan pengukuran densitas bahan, semakin tinggi densitas sintering maka porositas menurun.

Tabel 1. Data hasi uji porositas

\begin{tabular}{|c|c|c|c|c|c|}
\hline \multicolumn{3}{|c|}{ Komposisi } & \multicolumn{3}{|c|}{500 oC } \\
\hline Al (\%) & SIC (\%) & $\mathrm{Al}_{2} \mathrm{O}_{3}(\%)$ & $\begin{array}{c}1 \text { Jam } \\
\text { (\%) }\end{array}$ & $\begin{array}{c}3 \text { Jam } \\
\text { (\%) }\end{array}$ & $\begin{array}{c}6 \text { Jam } \\
\text { (\%) }\end{array}$ \\
\hline \multirow{13}{*}{80} & 17 & 3 & 19.246 & 17.120 & 11.901 \\
\hline & 14 & 6 & 16.508 & 13.087 & 11.434 \\
\hline & 11 & 9 & 16.335 & 10.108 & 8.448 \\
\hline & & & \multicolumn{3}{|c|}{550 oC } \\
\hline & & & $\begin{array}{c}1 \text { Jam } \\
(\%)\end{array}$ & $\begin{array}{c}3 \text { Jam } \\
(\%)\end{array}$ & $\begin{array}{c}6 \text { Jam } \\
(\%)\end{array}$ \\
\hline & 17 & 3 & 12.266 & 11.842 & 11.198 \\
\hline & 14 & 6 & 10.922 & 10.488 & 10.165 \\
\hline & 11 & 9 & 10.766 & 8.448 & 8.168 \\
\hline & & & \multicolumn{3}{|c|}{600 oC } \\
\hline & & & $\begin{array}{c}1 \text { Jam } \\
(\%)\end{array}$ & $\begin{array}{c}3 \text { Jam } \\
(\%)\end{array}$ & $\begin{array}{c}6 \text { Jam } \\
(\%)\end{array}$ \\
\hline & 17 & 3 & 11.775 & 10.942 & 6.892 \\
\hline & 14 & 6 & 9.740 & 8.034 & 3.551 \\
\hline & 11 & 9 & 9.657 & 5.885 & 2.439 \\
\hline
\end{tabular}

Dari tabel 1 terlihat bahwa hasil pengujian porositas Aluminium matrix composite (AMC) dengan matrik $\mathrm{Al}$ diperkuat $\mathrm{SiCw}$ aditif $\mathrm{Al}_{2} \mathrm{O}_{3}$. Keberadaan porositas yang terletak pada daerah antarmuka antara serbuk matrik dan penguat menyebabkan terhalangnya pembentukan ikatan antar partikel penguat sepanjang proses kompaksi maupun pembentukan sepanjang proses sintering terlihat pada tabel 1 semakin naiknya $\mathrm{Al}_{2} \mathrm{O}_{3}$ yang besifat sebagai pengisi yang halus sehinga bisa mengisi rongga-rongga dari komposit sehingga porositas semakin mengecil.

Tabel 2. Komposisi komposit $\mathrm{Al} /\left(\mathrm{SiC}+\mathrm{Al}_{2} \mathrm{O}_{3} \mathrm{p}\right)$

\begin{tabular}{|c|c|c|c|}
\hline \multicolumn{4}{|c|}{ Proses Pencampuran } \\
\hline Komposisi & Al Powder & $\mathbf{S i C w}$ & $\mathbf{A l}_{\mathbf{2}} \mathbf{O}_{\mathbf{3}}$ \\
\hline 1 & $80 \%$ & $17 \%$ & $3 \%$ \\
\hline 2 & $80 \%$ & $14 \%$ & $6 \%$ \\
\hline 3 & $80 \%$ & $11 \%$ & $9 \%$ \\
\hline
\end{tabular}




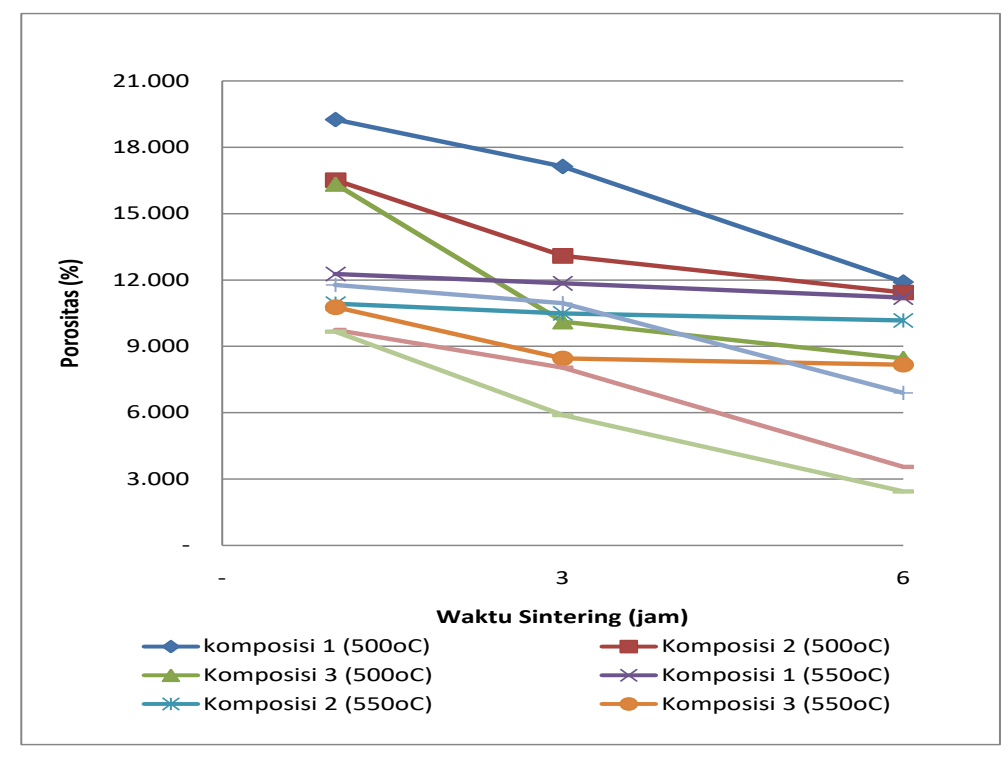

Gambar 4 Grafik hubungan antara porositas dengan waktu sintering

Pada gambar 4 dapat dilihat semakin tinggi prosentase $\mathrm{SiCw}$ semakin tinggi pula porositas dari komposit, dan semakin naiknya suhu dan waktu tahan sintering semakin menurunkan sifat porositas. Porositas tertinggi terdapat pada $80 \% \mathrm{Al}+\left(17 \% \mathrm{SiCw}+3 \% \mathrm{Al}_{2} \mathrm{O}_{3}\right)$ dengan $1 \mathrm{jam}$.

\section{Pengujian Konduktivitas Termal}

Dari data-data pengujian dan analisis data, menunjukan distribusi nilai pada setiap temperatur dan waktu yang berbeda mendapatkan nilai yang berbeda pula. Dari tabel ditunjukkan dari prosentase, suhu dan waktu sintering yang berbeda dari pengukuran T1, - T11. Pada pengujian konduktivitas termal dengan pemberian sumber kalor 100 Watt yang menjadi pusat penelitian yaitu dari T4 ke T5 yaitu letak dari benda uji, berapa tinggi pengantar panas dari pada komposit. Dapat dilihat pada tabel 3.

Tabel 3 Data hasi uji Konduktivitas panas

\begin{tabular}{|c|c|c|c|c|c|}
\hline \multicolumn{3}{|c|}{ Komposisi } & \multicolumn{3}{|c|}{500 oC } \\
\hline Al (\%) & SIC (\%) & $\mathrm{Al}_{2} \mathrm{O}_{3}(\%)$ & $\begin{array}{l}1 \mathrm{Jam} \\
\mathrm{Kcal} / \mathrm{mh} \text { oC }\end{array}$ & $\begin{array}{l}3 \mathrm{Jam} \\
\mathrm{Kcal} / \mathrm{mh} \text { oC }\end{array}$ & $\begin{array}{l}6 \mathrm{Jam} \\
\mathrm{Kcal} / \mathrm{mh} \text { oc }\end{array}$ \\
\hline & 17 & 3 & 34.874 & 85.495 & 150.528 \\
\hline & 14 & 6 & 198.396 & 198.397 & 221.426 \\
\hline & 11 & 9 & 287.675 & 328.407 & 412.971 \\
\hline & & & & 550 oC & \\
\hline & & & $\begin{array}{c}1 \text { Jam } \\
\mathrm{Kcal} / \mathrm{mh} \text { oC }\end{array}$ & $\begin{array}{c}3 \text { Jam } \\
\text { Kcal/mh oC }\end{array}$ & $\begin{array}{c}6 \text { Jam } \\
\mathrm{Kcal} / \mathrm{mh} \text { oC }\end{array}$ \\
\hline \multirow[t]{8}{*}{80} & 17 & 3 & 161.389 & 185.597 & 191.783 \\
\hline & 14 & 6 & 221.426 & 226.575 & 261.386 \\
\hline & 11 & 9 & 290.907 & 332.139 & 414.887 \\
\hline & & & & $600 \mathrm{oC}$ & \\
\hline & & & $\begin{array}{c}1 \text { Jam } \\
\mathrm{Kcal} / \mathrm{mh} \text { oC }\end{array}$ & $\begin{array}{c}3 \text { Jam } \\
\mathrm{Kcal} / \mathrm{mh} \text { oC }\end{array}$ & $\begin{array}{c}6 \text { Jam } \\
\mathrm{Kcal} / \mathrm{mh} \text { oC }\end{array}$ \\
\hline & 17 & 3 & 191.783 & 193.937 & 193.939 \\
\hline & 14 & 6 & 232.199 & 237.628 & 282.239 \\
\hline & 11 & 9 & 335.956 & 339.863 & 455.111 \\
\hline
\end{tabular}


Nilai kondutivitas termal pada masing-masing spesimen dengan pariasi yang berbeda sesuai gambar 5, dimana semakin meningkatnya temperatur suhu sintering dan prosentase $\mathrm{Al}_{2} \mathrm{O}_{3}$ nilai konduktivitas termalnya semakin meningkat pula pada peningkatan waktu ( 1 jam, 3 jam dan 6 jam) dengan nilai tertinggi pada $\mathrm{Al} 80 \%$, SiC $11 \%, \mathrm{Al}_{2} \mathrm{O}_{3} 9 \%$ yaitu berturut-turut $\left(500^{\circ} \mathrm{C}\right)$ adalah $412.971 \mathrm{kcal} / \mathrm{mh}^{\circ} \mathrm{C},\left(550^{\circ} \mathrm{C}\right)$ adalah $414.887 \mathrm{kcal} / \mathrm{mh}{ }^{\circ} \mathrm{C}$ dan tertinggi di temperatur $\left(600^{\circ} \mathrm{C}\right)$ adalah $455.111 \mathrm{kcal} / \mathrm{mh}{ }^{\circ} \mathrm{C}$. Hubungan antara konduktivitas termal dengan waktu sintering yang diteliti tampak jelas kelihatan peningkatan konduktivitas panas dengan meningkatnya perlakuan temperatur dan waktu tahan sintering.

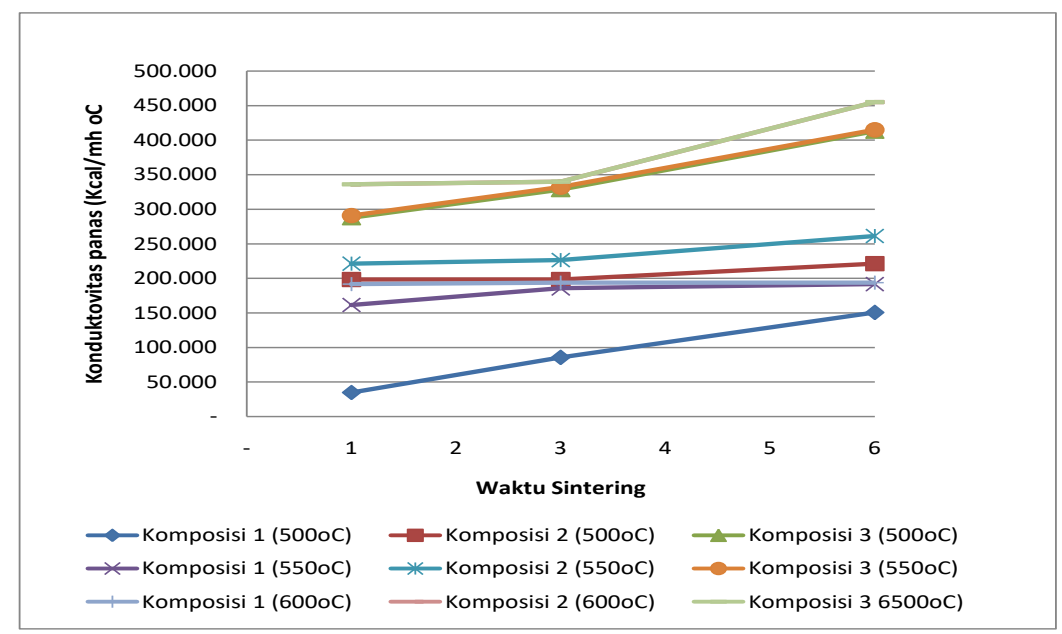

Gambar 5 Grafik hubungan antara konduktivitas termal dengan waktu sintering

\section{Pengaruh Penguat $\mathrm{SiCw}$ dan $\mathrm{Al}_{2} \mathrm{O}_{3}$ terhadap Kekerasan}

Gambar 6 menunjukkan hubungan antara komposisi persentase berat dari komposit $\mathrm{Al} /\left(\mathrm{SiCw}+\mathrm{Al}_{2} \mathrm{O}_{3} \mathrm{p}\right)$ dengan kekerasan. Hal ini dapat dilihat bahwa setiap peningkatan komposisi gabungan penguat $\mathrm{SiCw}$ dan $\mathrm{Al}_{2} \mathrm{O}_{3}$ dengan komposisi matriks Aluminium, menyebabkan peningkatan dalam kekerasan. Temuan ini mirip dengan penelitian sebelumnya (Froyen, 1994 dan Widyastuti, et al. 2008) bahwa semakin besar jumlah komposisi penguat yang digunakan, semakin tinggi nilai kekerasan yang diperoleh dan terjadi peningkatan ikatan antar partikel. Umumnya setiap penambahan penguatan pada aluminium matriks menyebabkan peningkatan kekerasan komposit. Dalam hal ini, efek penambahan $\mathrm{Al}_{2} \mathrm{O}_{3}$ sendiri berdampak pada kekerasan komposit. Pada tabel 4 ditampilkan data pengaruh komposisi persentase berat penguat $\mathrm{SiCw}$ dan $\mathrm{Al}_{2} \mathrm{O}_{3}$ pada aluminium matrik terhadap kekerasan komposit. Nilai kekerasan komposit penguat $\left(\mathrm{SiCw}+\mathrm{Al}_{2} \mathrm{O}_{3} \mathrm{p}\right)$ pada $80 \% \mathrm{Al}$ dengan penguat berturut-turut : $\left(17 \% \mathrm{SiCw}+3 \% \mathrm{Al}_{2} \mathrm{O}_{3}\right)$, $\left(14 \% \mathrm{SiCw}+6 \% \mathrm{Al}_{2} \mathrm{O}_{3}\right)$, dan $\left(11 \% \mathrm{SiCw}+9 \% \mathrm{Al}_{2} \mathrm{O}_{3}\right)$ menunjukan adanya peningkatan kekerasan pada temperatur sintering $600^{\circ} \mathrm{C}$. Hal ini juga terjadi karena peningkatan dari penguat persentase berat $\mathrm{Al}_{2} \mathrm{O}_{3}$. Salah satu sifat dari $\mathrm{Al}_{2} \mathrm{O}_{3}$ adalah keras (brittle) dan keuletan yang rendah. Disisi lain, nilai kekerasan komposit meningkat dengan penurunan persentase berat penguatan gabungan $\mathrm{SiCw}$. Jadi nilai kekerasan meningkat dengan penguatan : $\mathrm{Al}_{2} \mathrm{O}_{3}$ dari 3\%wt, 6\%wt dan 9\%wt, untuk masing-masing komposit matriks aluminium.

Pada gambar 6 terlihat jelas kekerasan meningkat karena $\mathrm{Al}_{2} \mathrm{O}_{3}$ sendiri, partikel kecil dapat masuk sendiri dengan mudah dan merata antara partikel matriks aluminium. Hasil penelitian menunjukkan bahwa persentase yang lebih tinggi pada berat gabungan dari $\mathrm{SiCw}$ dan $\mathrm{Al}_{2} \mathrm{O}_{3}$ penguat dalam matriks aluminium dapat meningkatkan nilai kekerasan. Penguatan komposit mempengaruhi sifat mekanik yang dibuktikan dengan peningkatan nilai kekerasan komposit. 
Nilai kekerasan komposit tertinggi pada penelitian ini $\left(11 \% \mathrm{SiCw}+9 \% \mathrm{Al}_{2} \mathrm{O}_{3}\right)$ menunjukan adanya peningkatan kekerasan pada temperatur sintering $600^{\circ} \mathrm{C}$ dengan nilai $182,090 \mathrm{VHN}$.

Tabel 4 Data hasi uji kekerasan

\begin{tabular}{ccc|ccc}
\hline \multicolumn{3}{c|}{ Komposisi } & \multicolumn{3}{c}{600 oC } \\
\hline \multirow{2}{*}{$\mathrm{Al}(\%)$} & $\mathrm{SIC}(\%)$ & $\mathrm{Al}_{2} \mathrm{O}_{3}(\%)$ & $\begin{array}{c}1 \mathrm{Jam} \\
\text { VHN }\end{array}$ & $\begin{array}{c}3 \mathrm{Jam} \\
\text { VHN }\end{array}$ & $\begin{array}{c}\text { V Jam } \\
\text { VHN }\end{array}$ \\
\hline \multirow{3}{*}{80} & 17 & 3 & 103,602 & 125,978 & 150,722 \\
& 14 & 6 & 116,497 & 134,264 & 165,959 \\
& 11 & 9 & 124,100 & 141,046 & 182,090 \\
\hline
\end{tabular}

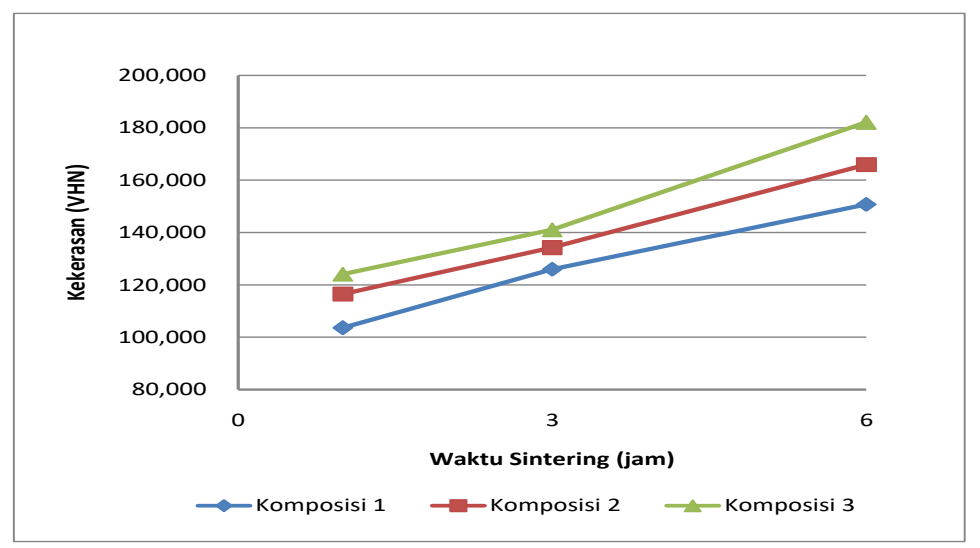

Gambar 6 Grafik hubungan antara kekerasan dengan waktu sintering

\section{KESIMPULAN DAN SARAN}

1. Karakteristik komposisi persentase berat (\%wt) penguat pada komposit $\mathrm{Al}+\left(\mathrm{SiC}+\mathrm{Al}_{2} \mathrm{O}_{3}\right)$ memberikan efek terhadap sifat fisik porositas menurun dengan peningkatan penguat dari alumina, porositas terendah didapat $\left(\rho=3.155 \mathrm{gr} / \mathrm{cm}^{3}\right)$. Sifat porositas menurun disetiap peningkatan $\mathrm{Al}_{2} \mathrm{O}_{3}$.

2. Sifat konduktivitas termal pada komposit $\mathrm{Al} /\left(\mathrm{SiC}+\mathrm{Al}_{2} \mathrm{O}_{3}\right)$ terjadi peningkatan dengan meningkatnya komposisi penguat $\mathrm{Al}_{2} \mathrm{O}_{3}$ pada temperatur dan waktu sintering dimana paling baik terdapat pada $\mathrm{Al} /\left(11 \% \mathrm{SiC}+9 \% \mathrm{Al}_{2} \mathrm{O}_{3}\right)$ pada waktu sintering 6 jam dan di suhu $600^{\circ} \mathrm{C}$ dengan hasil adalah $455.111 \mathrm{kcal} / \mathrm{mh}{ }^{\circ} \mathrm{C}$.

3. Perlakuan komposisi persentase berat $(\% \mathrm{wt})$, temperatur dan waktu tahan memberikan pengaruh terhadap kekerasan dari $\mathrm{Al} /\left(\mathrm{SiC}+\mathrm{Al}_{2} \mathrm{O}_{3}\right)$ yaitu semakin bertambahnya $\mathrm{Al}_{2} \mathrm{O}_{3}$, waktu tahan dan temperatur semakin meningkat sifat kekerasan.

\section{Ucapan Terima Kasih (Acknowledgement)}

Terimakasih kepada LPPM Unud yang mendanai penelitian ini, Laboratorium Metalurgi Teknik Mesin Universitas Udayana, Kepala Laboratorium Metalurgi Institut Teknologi (ITN) Malang dan Kepala Laboratorium Metalurgi Jurusan Teknik Mesin Universitas Brawijaya Malang. 


\section{REFERENSI}

Ahmad, K. R. 2005. The Influence of Alumina Particle Size on Sintered Density and Hardness of Discontinous Reinforced Aluminum Metal Matrix Composites, Jurnal Teknologi 42 (A), University Teknologi Malaysia.

Brandt, N.G.L. and Senesan, Z. D., 1995, Ceramic Cutting Tool Reinforced by Whiskers, United State Patent, No. RE35,090.

Froyen, B. Verlinden 1994. Aluminium Matrix Composites Materials. Talat 1402. Belgium. European Aluminium Associations (EAA).

Garnier, V., Fantozzi, G., Nguyen, D., Dubois, J. and Thollet, G. 2005. Influence of SiC whisker Morphology and Nature of $\mathrm{SiC} / \mathrm{Al}_{2} \mathrm{O}_{3}$ Interface on Thermo Mechanical Properties of $\mathrm{SiC}$ Reinforced $\mathrm{Al}_{2} \mathrm{O}_{3}$ Composites. Journal of the European Ceramic Society, 25, 34853493. doi : 10.1016/ j. jeurceramsoc.2004.09.026

Gibson Ronald, F. 1994. Principles of Composite Material Mechanics. Singapore : McGrawHill.

Goto, Ryuichiro, (2013). Powder Metallurgy Growth in The Automotive Market. American Powder Metals Industries International.

Suarsana, Putu Wijaya Sunu, (2015). Studi Eksperimen Pembuatan Komposit Metal Matrik Aluminium Penguat $\mathrm{SiC}$ Wisker dan $\mathrm{Al}_{2} \mathrm{O}_{3}$ Partikel sebagai Material Alaternatif. Jurusan Teknik Mesin Fakultas Teknik Universitas Udayana Bukit Jimbaran Bali, Indonesia.

Widyastuti, et al. 2008. Kompaktibilitas Komposit Isotropik Al/Al2O3 dengan Variabel Waktu Tahan Sinter. Departemen Metalurgi dan Material, Fakultas Teknik, Universitas Indonesia, Depok 16424, Indonesia

Zainuri, N.A., Nopiah, Z.M., Razali, N., Asshaari, I. \& Othman, H. (2009). The study on the weaknesses of mathematical foundation in the first year engineering students, UKM, Prosiding Seminar Pendidikan Kejuruteraan \& Alam Bina (PeKA09), 226-233. 